\section{Evaluation of dry port implementation in Ghana}

Kwame Owusu Kwateng, Archibald Donkoh and

Abdul Samed Muntaka

Department of Supply Chain and Information Systems, School of Business, Kwame Nkrumah University of Science and Technology, Kumasi, Ghana

\begin{abstract}
Purpose - Congestion at Ghana's main seaports is a problem that has received much attention recently. This is as a result of continuous increase in containerized cargo. To increase the capacity of Ghana' seaport, the Ministry of Transport through the Ghana Shippers Council initiated the Boankra Inland Port Project. The aim of this paper is to assess the feasibility and economic effects of implementing the Boankra Inland Port as a solution to reduce congestion at the main seaports, as well as reduce transportation cost.
\end{abstract}

Design/methodology/approach - The location of the inland port was assessed using the gravitational model. Data for the gravitational model are distances from the main seaports in Ghana and Boankra Inland Port to major hinterland destinations and population of the destinations. Also, 210 respondents were selected and interviewed on contribution of the dry port concept to the economy and transportation management in Ghana.

Findings - The results of the gravitational model support the location of Boankra as an inland port. A further comparison between Tema and Takoradi shows that Tema has a better location as a distribution center than Takoradi.

Practical implications - Although Tema and Takoradi are the main seaports in Ghana, the implementation of the Boankra inland port will reduce the transportation cost for cargo with hinterland destinations, therefore making it a rational and cost-efficient location for transit transportation.

Originality/value - This paper is among the first significant attempts to evaluate the suitability of inland port implementation in Ghana.

Keywords Transport, Ghana, Dry port, Gravitational model, Inland port

Paper type Research paper

\section{Introduction}

The movement of goods/products from the producer to the consumer is referred to as transportation. It is the cause of most cost incurred in the supply chain. Because products are not produced and consumed at one place, transportation becomes an integral part of every supply chain (Chopra and Meindl, 2007). The emergence of global trading has resulted in the increase in global cargo tonnage. Thus, one of the most important part of globalization, freight distribution and seaborne transportation is the inland distribution (Notteboom and Rodrigue, 2005). This explains the emergence of dry ports in most supply chain networks around the world. The dry port concept emphasizes rail transport from seaport to inland intermodal terminals widely referred to as inland port. The concept is geared toward improving the cost-efficiency and the capacity of the transportation system. It is also environmental friendly and decreases the external cost of the road transport

(C) Pacific Star Group Education Foundation

\section{Dry port implementation}

Received 31 January 2017 Revised 28 April 2017 12 July 2017

Accepted 4 August 2017 
MABR

2,3

system. It will also help to reduce accidents, congestion and noise throughout the transportation system (Roso, 2009a, 2009b; Roso et al., 2008).

In Ghana, the recent growth in cargo traffic at the main seaports (Takoradi and Tema) motivated the expansion of their capacities and the need for other ideal arrangements to ease congestion at the ports. The complexities of the Ghanaian supply chain system include increased transportation cost and lead times (Chopra and Meindl, 2007). Thus, without the necessary measures put in place, Tema and Takoradi ports which are Ghana's main seaports will be strained to their capacity limits. The aim of the transport policy is to make Ghana the transportation hub for the West African sub region. This transport system is expected to improve user experience through reliable, efficient, affordable, accessible, effective, sustainable, safe and secure transport system. There is gradual shifting from port terminals and maritime shipping network development to inland port development, and hence the development of the proposed Boankra Inland Port Project by the Government of Ghana. The project is inspired by the world focus on capacity and co-modal and intermodal transportation options. It is expected that the dry port or inland port implementation would provide solution for congestion, energy consumption and empty movement. This paper will study the proposed Boankra Inland Port Project and the influence of its implementation on supply chain management in Ghana and other landlocked countries. The paper will introduce the dry port concept and investigate its feasibility, characteristics, economic effects and challenges.

\section{Literature review}

\section{Transportation in Ghana}

Inland transportation of cargo in Ghana is mostly by road, rail and water. A vast majority of haulage depends on road transport making it the most extensive and widely used mode. Rail transport serves as a major alternative for road transport in the carrying of freight. The rail network is limited to the southern part of Ghana, specifically the Greater Accra, Central, Western, Eastern and Ashanti regions (Commerce Ghana, 2012). Another mode of transport used in Ghana which is a cheaper alternative to rail and road transport is water. The Volta lake, as a waterway, is used in the transportation of both general and liquid bulk cargo (Ghana Investment and Promotion Centre [GIPC], 2015).

Road transport is the predominant mode of transport and plays an important role in supply chain in Ghana. It is the most accessible transportation mode, and on estimation, accounts for 94 per cent of freight (Ghana National Commission for UNESCO, 2009/2010). An improvement in the road network of Ghana has led to its positioning as a hub for cargo transit business in West Africa, facilitating the exchange of commodities. Ghana's road networks are categorized into trunk roads, feeder roads and urban roads. Estimation shows that Ghana has about 67,488 $\mathrm{km}$ of road network as of 2009. Of this, $12,839 \mathrm{~km}$ are trunk roads, $42,209 \mathrm{~km}$ are feeder roads and 12,400 km are urban roads (Ghana National Development Planning Commission, 2013). There has been a greater efficiency in the road transport sector because of the privatization of Ghana's transport and logistics entities. Transportation of cargo to and from the main seaports relies mainly on road transport; therefore, more investment in this sector is needed to facilitate the import and export of goods.

The rail sector in Ghana has a relatively very small share of the transport market accounting for an estimation less than 2 per cent of freight (Ghana National Commission for UNESCO, 2009/2010). The rail network is 1,300 km which links Kumasi, Takoradi and Accra-Tema. The network links mainly the agro and mining regions to the main seaports in 
Ghana, serving as a means of hauling cocoa, timber, cement and minerals (GIPC, 2015). There has been a decline in the volume of freight carried by rail which is attributed to the deterioration of the rail network, decreasing wagons and lack of investment in the freight sector (Ghana National Commission for UNESCO, 2009/2010). With the necessary structures in place, the rail sector has the potential to be an alternative to road transport in the transportation of freight. The Government of Ghana has therefore developed a long-term plan to revamp the sector and also expand it to the northern parts of Ghana. Rail transport has been researched to be a more environmental friendly and cost-efficient transportation mode [The European Rail Research Advisory Council (ERRAC), 2014]. This is because, rail transport consumes less energy, and its carbon dioxide emission is less than road transport. Cost of rail transport in Ghana is less than road transport. Presently, the rail network of Ghana is in a poor state unlike the road network which has experienced marked improvement. Also, rail transport has a limited distance therefore there is a need to revamp to make it viable.

\section{Ports in Ghana}

\section{Tema Port}

The Tema port is Ghana's first ranked port and serves as a major transit point for goods to and from the landlocked countries. It is Ghana's biggest port and principal cargo gateway which handles nearly 70 per cent of the nation's total seaborne trade and about 35 per cent of its exports. Container handling is a core business for Tema, which has seen a high rise in traffic over the past 10 years (Figure 1). Tema is widely recognized as a regional hub, handling over 893,000 Twenty-Foot Equivalent Units (TEU) in 2016 (Figure 1) compared with about 420,000 TEU in 2006. TEUs of container traffic for Tema port from 2003 to 2016 are summarized in Figure 1.

The port has seen a dramatic increase in transshipment of containers as well as transit traffic to and from the landlocked countries of Burkina Faso, Mali and Niger (Figure 2). About 12 million tons of cargo was handled by the port in 2016 (GPHA Port Statistical Report, 2017). To make Tema more competitive in the sub region, the Ghana Ports and Harbours Authority (GPHA) is improving the port's cargo handling efficiency and speeding the flow of traffic. Investments have been made in new berths with more depth to accommodate larger vessels as well as new cranes and other handling equipment. New

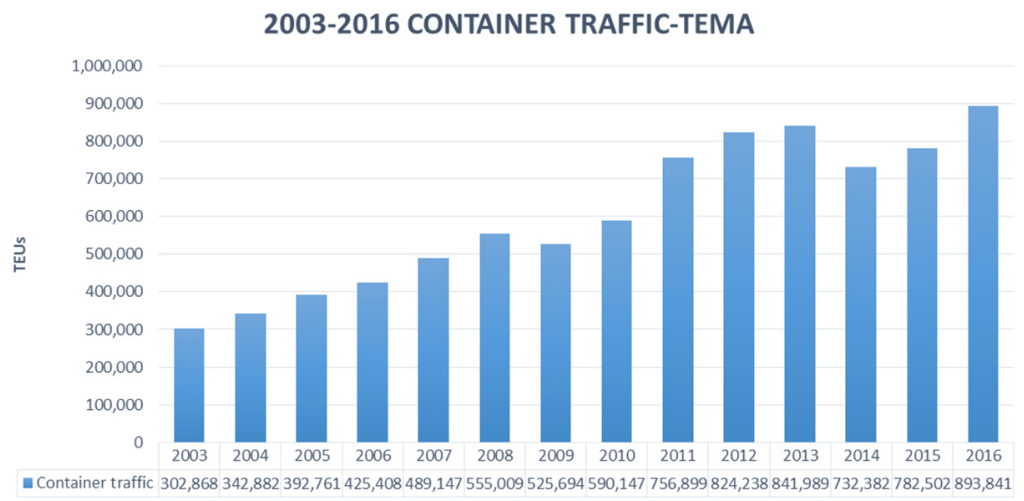

Source: GPHA Report (2017)

Figure 1. TEUs of container traffic at Tema Port 
MABR

2,3

264

Figure 2.

TEUs of

transshipment at

Tema Port transit traffic by destination 2003-2016

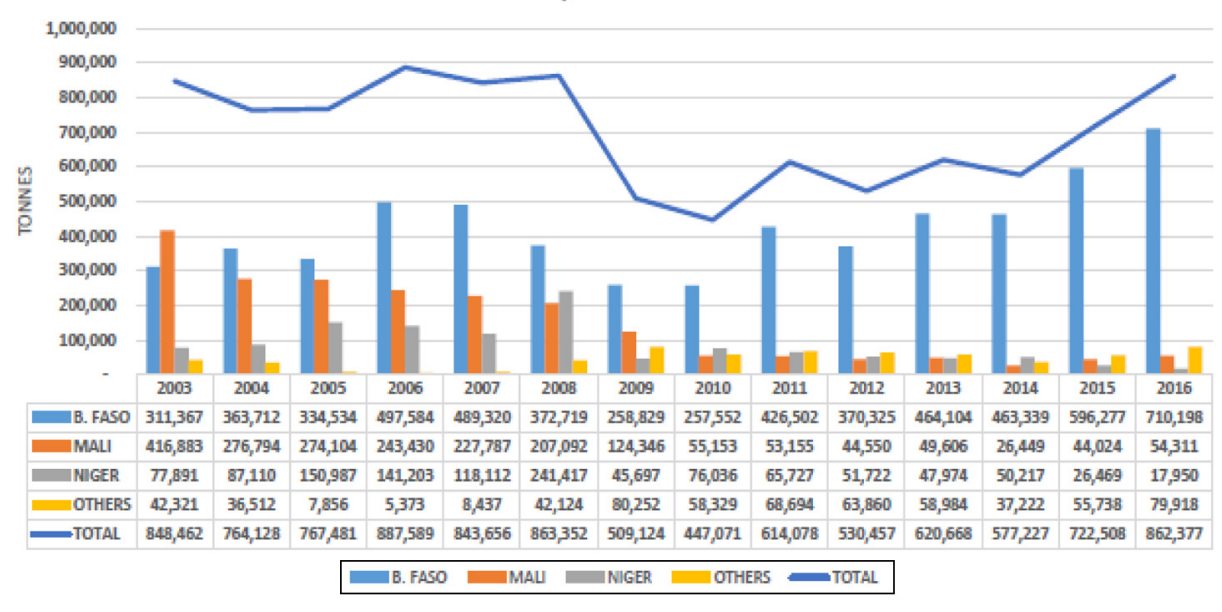

Source: GPHA Report (2017)

container terminals have been opened for stacking and handling. Also, an automated scanning system has been introduced at the Tema port to speed up the clearance of containers which helps in solving problems associated with congestion. Scanners are now used for the examination of contents of containers. This system has taken over the physical examination of homogenous goods and has lessened cargo handling and port congestion, ultimately reducing cost to the customer.

Tema port serves as Ghana's main gateway for transit traffic to and from the landlocked countries such as Burkina Faso, Mali and Niger (Figure 2). This traffic has been driving up cargo throughput at Tema, particularly containers. Transshipment is a key factor in the rapid growth of container traffic in Tema. The level of transshipment keeps on increasing. Containers are transshipped in Tema not only for other ports in West Africa but also to and from international destinations such as South Africa, Middle East and Asia. The boom in transshipment has therefore attracted interest from major shipping lines.

Both imports and exports (Table I) through Tema have been rising steadily, and container traffic has seen a tremendous growth of over 50 per cent in the past three years (GPHA Report, 2017).

To cope with the level of traffic, GPHA is building new larger container terminals. This allows incoming containers to be moved out of the port to a dedicated area for full container loads to be divided into smaller lots for consignees. Previously, this used to take place in the port area leading to chronic congestion. The upsurge in imports and exports is a key factor in the rapid growth of container traffic congestion in Tema; therefore, there is a need to construct more container terminals. The implementation of Boankra Inland port will reduce the need for the development of container terminals, and funds can be diverted to other projects. Container traffic congestion will be reduced, and also, a substantial amount of truck traffic at the port will be diverted. This is because of the fact that, shipments that are destined for the hinterlands will be moved straight to the inland port for clearance. Boankra is $295 \mathrm{~km}$ from Tema port, and therefore, transportation cost and time will be reduced (Ghana Ports Handbook 2007-2008, 2008; Shipping Review, 2012). 


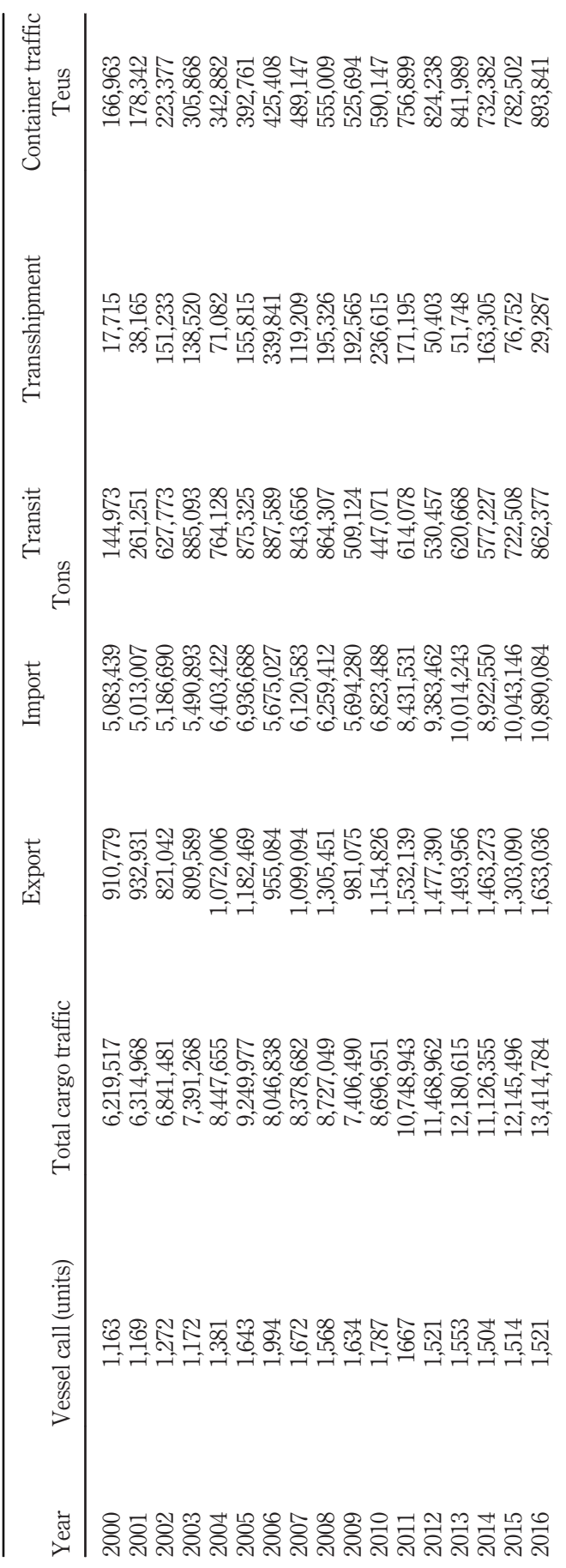

Dry port
implementation

265

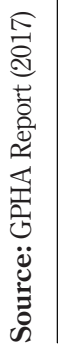

Table I.

Tema Port performance 2000-2016 
MABR

2,3

\section{6}

\section{Takoradi Port}

Takoradi port which is located in the western region of Ghana is the second-ranked port, and handles about 31 per cent of Ghana's seaborne traffic as of 2016 (Figure 3). It is a major export gateway for bulk products, especially minerals, and has also diversified into other types of traffic notably containers. In recent years, Takoradi port has seen a big rise in transit traffic to the landlocked countries. Although considerably smaller than Tema, it handles about 66 per cent of the nation's total exports and 19 per cent of the nation's import (Figure 4). A key advantage of Takoradi is its western location which offers a saving in voyage time for vessels coming from the north and west. The principal activity of the port is to handle exports of minerals from the mines of Western Ghana.

In addition, the port handles other bulk exports notably cocoa beans as well as loading and discharging other types of cargo. Port facilities have been expanded to handle large volumes of bagged cargo, breakbulk and containers, as well as vehicles, rolling plant and project cargo. Takoradi port's biggest traffic is minerals. Large quantities of bauxite and manganese are loaded for export yearly. Also, tons of ammonium nitrate, limestone, quicklime, as well as raw materials and equipment for the mines are also imported through Takoradi. The major customers of the port are Ghana Bauxite Company, Ghana Manganese Company and the oil and gas companies. Most of the traffic goes in bulk, but some are exported in bags or containers. In addition, the port handles containerized and project cargoes for the mining and oil and gas industry. Several gold mines and oil rigs are under construction, all requiring large quantities of equipment and machinery. The transit business in Takoradi continues to grow, and one reason for this growth is the good road links going through Takoradi. It offers a shorter route than Tema to the inland commercial center of Kumasi. Transit traffic at the Takoradi port has increased dramatically because of the oil and gas discovery in the western region of Ghana. The distance from Takoradi to Boankra is $330 \mathrm{~km}$, and it is expected that the implementation of the inland port will reduce transportation cost because transit goods will be transported by rail to the inland port for clearance by their owners who are mainly from the landlocked countries. Also, it will alleviate container and associated traffic congestion at the Takoradi port (Ghana Ports Handbook 2007-2008, 2008; Shipping Review, 2012).

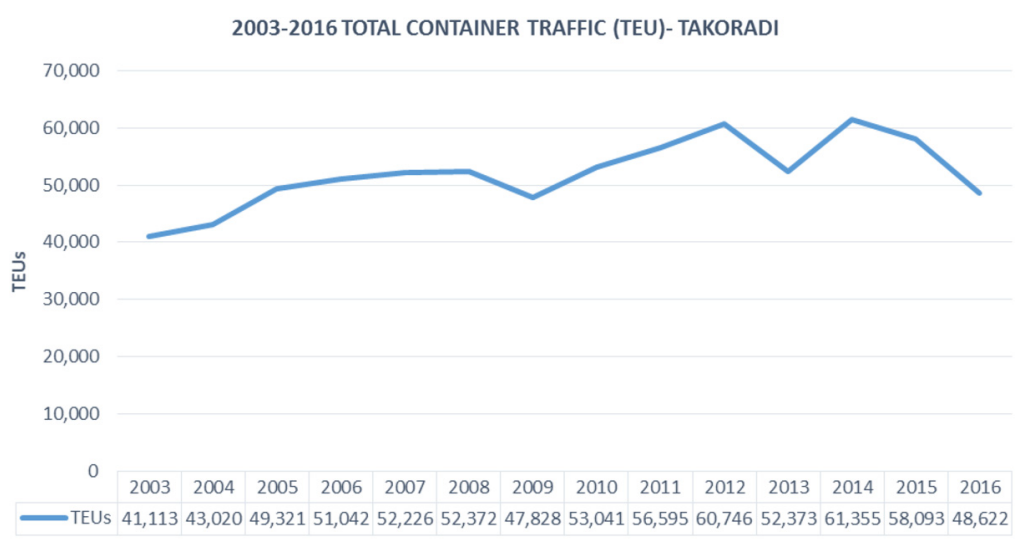

Source: GPHA Report (2017)
Figure 3.

TEUs of container traffic at Takoradi port 


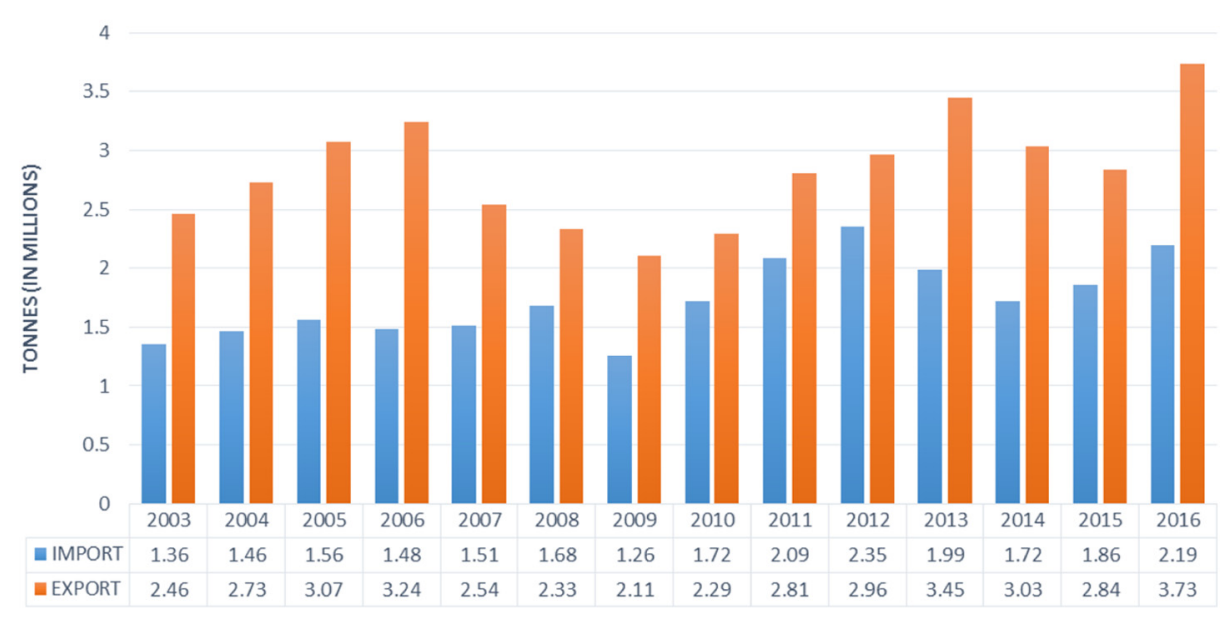

Source: GPHA Report (2017)

\section{Dry port implementation}

267

\section{Boankra Inland Port}

This port is a joint venture between Ghana Shippers Council and GPHA. The port is approximately equidistant from both Tema and Takoradi ports. The dry port is a staging post for traffic to and from northern Ghana and the transit countries. It is also expected to help relieve pressure on both ports in terms of clearance procedures and storage space. Boankra is a full multimodal cargo handling facility with customs services, financial companies and value-added activities. For shippers, a key advantage of the new inland port is that cargo in transit to and from the landlocked countries to the north can be cleared from Boankra, so they can avoid the cost and time of traveling to the southern ports to clear cargo. Current international trade forecast by the Ghana Shippers Authority shows that global cargo tonnage increases annually. Thus, proactive measures need to be implemented to maintain the country's competitive advantage. The projected increases can easily be handled if cargo destined for hinterlands are moved away from the main seaports.

\section{The dry port concept}

It is empirically evidenced that the development of human settlements and the associated quest for socioeconomic development has inter alia, which led to the development of transportation infrastructure; the transportation infrastructure facilitates the movement of goods and services, as well as people. The transportation system has gone through various stages of development giving birth to the dry port concept.

According to Roso (2009):

[...] the dry port concept is based on a seaport directly connected by rail to inland intermodal terminals, where shippers can leave and/or collect their goods in intermodal loading units as if directly at the seaport. In addition to the transshipment that a conventional inland intermodal terminal provides, services such as storage, consolidation, depot, maintenance of containers and customs clearance are also available at dry ports. 
MABR

2,3

268
Figure 5.

Comparison between conventional hinterland transport and an implemented three types of dry port concept
In these times of growing container transport volumes, inland seaport access becomes a critical competitive advantage tool for the seaport (Roso, 2009b). The dry port performance may be measured by the quality of access to the dry port and the quality of the road-rail interface (Roso et al., 2008). A key measure that is taken to enhance the competitive advantage of seaports and entire transportation systems is to enhance the inland access of the seaport. The services of the dry port are similar to that of the seaports. The dry port concept is based on the intermodal transportation system, while the dry port is based on the inland intermodal terminal with additional services located inland (Figure 5). The seaport and the dry port are connected by rail (Figure 5). A reliable network of road, rail and seaport ensure free movement of freight. The efficiency of a seaport is enhanced by the implementation of a dry port because of the fact that activities at the seaport are outsourced to the dry port. This relieves the seaport and enables it to concentrate on core activities and competencies. The dry port exhibits the features such as inland intermodal terminal and rail connection between seaports and offers services that have traditionally been performed at seaports (Figure 5) (Roso, 2009a). Ports respond to congestion by expanding hinterland areas.

Because the inland port serves the seaport, it is located in the hinterland areas of the seaport. Different inland ports may be serving more than one seaport. Thus, seaports may share hinterland areas with other seaports. Figure 5 illustrates a comparison of a conventional transport and an implemented inland port concept. The upper part of Figure 5 illustrates a conventional transport, and the lower part illustrates a seaport and all three types of inland ports. The figure indicates a shortened road transport and freight connections because shippers will access nearest inland port instead of always transporting freight to the seaport city. The figure shows one rail and ten road connections to and from the seaport. The inland port solution is able to reduce it to only three rail connections to and
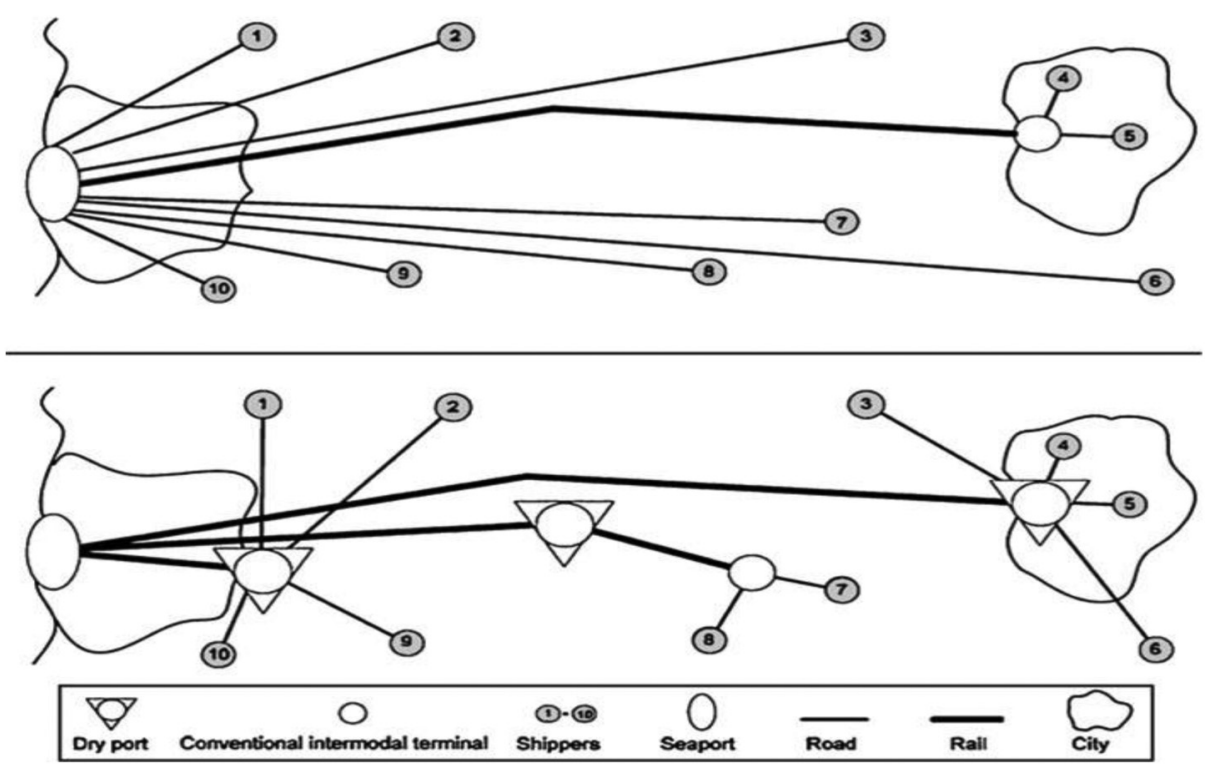

Source: Roso et al. (2006) 
from the seaport. The transportation system is highly relieved by the inland port system (Henttu et al., 2010).

\section{Types of dry ports}

Situating a possible dry port location involves the consideration of port or port's needs, as well as the areas of concentration with regard to shippers or recipients of the shipped goods. The railway connection length (distance of port from a dry port) definition could be determined with reference to the intermodal terminal allocation aspects. Furthermore, the dry port's implementation evaluation must not solely be based on the costs. The added value that can be accorded to the goods by a dry port, logistics chains and customers must also be factored in considerations.

Roso et al. (2006) and Woxenius et al. (2004) have carried out important research works on dry port distances. From these studies, dry ports can be classified into distant (Figure 6), midrange dry port (Figure 7) and close dry port (Figure 8), with further explanations and analysis on the different variations done. Establishing a dry port over a long distance (above $500 \mathrm{~km}$ ) away from a port while this location is close to vast areas of many manufacturers as

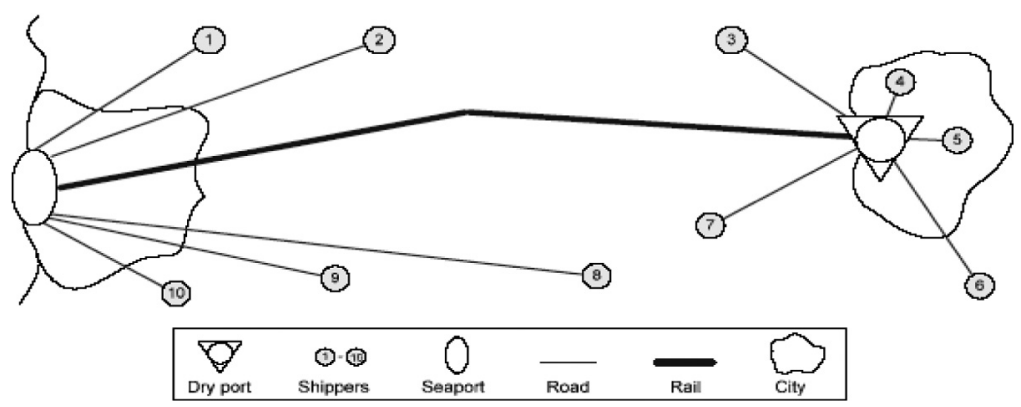

Source: Roso et al. (2006)

Figure 6. Connection of distant dry port to the port

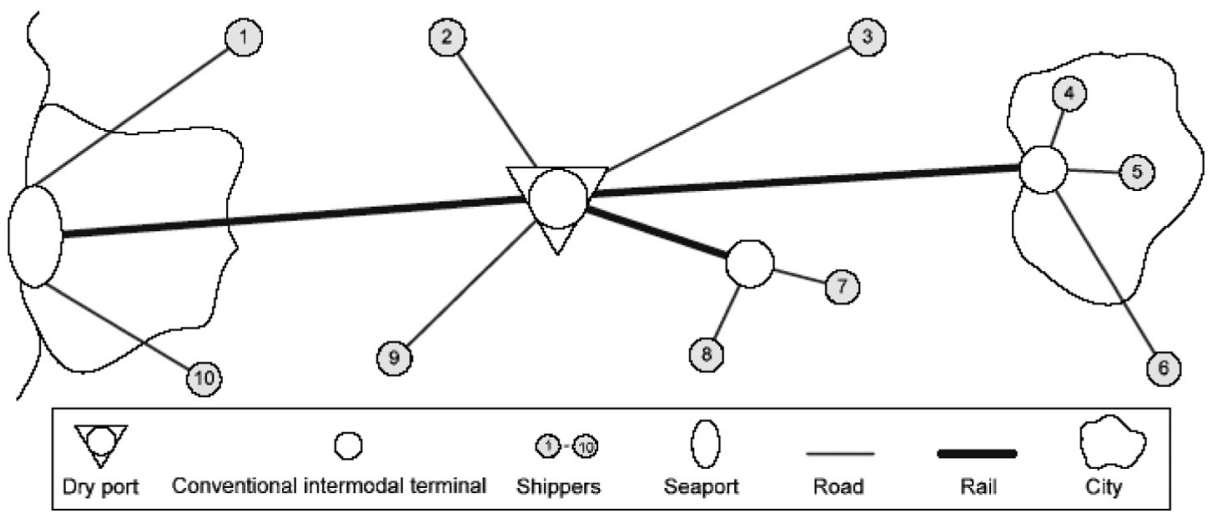

Source: Roso et al. (2006)

Figure 7. Midrange dry port connected to the port 


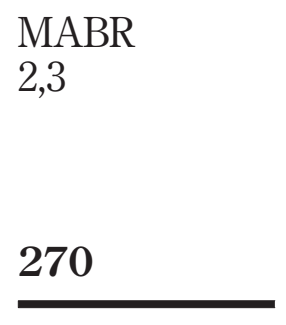

Figure 8.

Connection of close dry port to the port
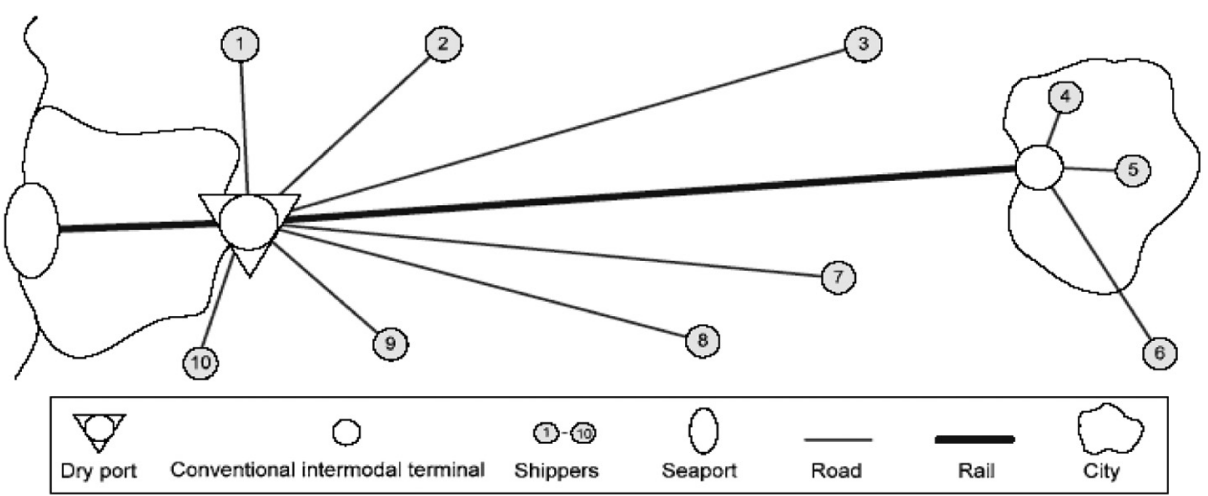

Source: Roso et al. (2006)

well as consumers is useful. With this in place, the distant dry port then has potential for receiving enormous quantities of goods, as it can serve as center for distribution to further locations or the node of consolidation for other shippers available nearby. It could also offer varied services linked not solely to consolidation and distribution. Below is an example of distant dry port in the illustrated figure. Important benefits can be derived taking into consideration that, instead of separately transporting goods by road to each shipper, all goods by shippers around the dry port area are moved to the port via rail transport.

Congestion around port areas as well as on access routes leading to the port is reduced in this practice. Also, the implementation of rail between the port and the dry port may yield some benefits to the environment because a single train can cart similar amount of goods as 40 trucks (Roso, 2006b). Rail transport has been proven to be two to five times more energyefficient and environmental friendly than road, shipping and aviation (The Voice of Europe Railways, 2008). Thus, key benefits can be obtained.

When increase in port capacity is not viable, especially in cases of the inability of the port to be expanded because of aspects of environmental concern or inhabitation of areas around port, as well as when storage area is lacking in the port, then either close dry port or midrange establishment is chosen. Inland midrange ports are located in between distant and close inland ports. Distance to seaport ranges between 100 and $500 \mathrm{~km}$ approximately. Inland midrange ports offer depot facilities usually. All other derived advantages are in similarity to inland distant ports (Roso et al., 2008; Roso, 2009b). Inland close ports are situated close to the actual sea port. Between an inland port and sea port, distance is less than $100 \mathrm{~km}$. Inland close ports offer security and consolidation for road transport, as well as from the seaport. Direct links by rail between seaports and inland ports offer seaport city streets relief (Roso et al., 2008; Roso, 2009b cited by Henttu et al., 2010, FDT, 2008). The illustrations of such dry ports are shown in the text.

The entire categories of inland ports share many similar advantages. Several players (including shippers, society, road operators, rail operators, seaports and seaport cities) exist that get varied advantages of the concept of inland ports. Implementation of inland ports leads to a reduction in congestion at the seaports' immediate proximity by modal shift to rail from road. While rail transportation frequency rises, congestion on the roads as well as seaport cities reduces as road transport diminishes. Because of the increase in transport of freight by rail, the rail transport operators obtain more share of the market. With credit to 
the inland ports, shippers acquire a larger range of logistics services. Inland ports enable regional development, lower impacts on the environment and increased job opportunities. Most obvious of the accrued advantages from an environmental view point stems from a modal shift to rail from road transport which discourages pollution and congestion (Woxenius et al., 2004; Roso et al., 2008 cited by Henttu et al., 2010, pp. 16-17).

\section{Current trends in dry port operations}

The development of dry ports is most advanced in Europe, especially Western Europe. Dry ports based on railways are usually linked to logistical zones development and are found all over Europe (Notteboom and Rodrigue, 2005). In addition, integration processes of Europe have enabled the set-up of more natural hinterlands (commercially dependent) specifically where a favorable allocation of the European market is found inland. Examples are Rotterdam and Antwerp. Since the nineteenth century, large inland terminals have been developed in North America to correspond to large inland markets such as Kansas and Chicago (Notteboom and Rodrigue, 2005). In Asia, inland terminals could be considered to be in their infancy, particularly in India, South Korea and Thailand. The greatest potential for manifestation of a system of inland terminals belongs to China.

Real implementations of dry port exist throughout the world, for instance, Sweden, USA and Tanzania, but the concept is not well-known (LAHTI, 2012). A typical example is the Port of Goteburg, which is Sweden's most important container port. It is found by the Kattegat Sea, an extension of North Sea in the south-west region of Sweden. Between the Port of Goteburg and a variety of Swedish inland terminals, daily shuttles of 24 rail journeys carts freight. In 2007 , the port handled over 840,000 TEU's a year, and truck transport accounted for 60 per cent to inland destinations as compared to 70 per cent in 2006 (Port of Göteborg AB, 2008).

This increase amounted to 3.6 per cent approximately in a single year period. Again, the comparison of change to 2007 was 3 per cent. The port has available space to expand borders if required because it is not located in the center of the Goteburg city. It becomes more costeffective financially to use an implementation of dry port and carry out extensions inland than the expansion of actual borders of seaports. This is because of to the increased value of land areas closer to the Goteburg city. Rail transport's modal share at Port of Goteburg has increased from the previous year's figures, and the future aim is to boost it even further (Bergqvist and Woxenius, 2011). Of all, 24 shuttles transported containers daily to and from Port Goteburg in 2009 in contrast to six shuttles daily in 2002. The surge in figures of shuttle train transport from 2002 toward 2009 amounts to a 300 per cent increase. In 2001, the number of TEUs transported via rail was around 115,000. The figure was 350,000 TEUs in 2008, implying 300 per cent approximate percentual chance. As at year 2010, 26 inland intermodal terminals served Port of Goteburg according to the Rail services (2010). In Sweden, there are five variant kinds of terminals in terms of rail freight comprising freeloading stations, lightcombination, conventional intermodal, IFCs (Intermodal Freight Centers) and wagon-load ones.

Another seaport that has adopted the dry port concept is the Virginia Port. Virginia Port is located in Southern USA, along the Atlantic Coast in Virginia. The Virginia Port comprises four facilities, namely, the Norfolk International Terminal, VA Inland Port, Portsmouth Marine Terminal and the Newport News Marine Terminal. The three terminals mentioned are seaports positioned by the sea and found at Hampton Roads. The Virginia Inland Port (VIP) operates as an implementation of dry port for seaside terminals and is situated inland. It is a typical instance of dry ports in the mid-range category that moves interfaces linking roads in the north-western direction of Front Royal 300 kilometers and above from Hampton Roads to rail. Port of Virginia has ownership of all facilities as well as the VIP. The dry port presents valuable space for further inland extension with its direct rail 
MABR

2,3

to sea terminal linkage facility. A competitive leverage is created by the dry port through the expansion of the Port of Virginia hinterland. It further augments access of the seaport to areas that traditionally do not belong to its hinterland. Container traffic was limited to the 1,800,000 TEUs per year level from the 2004-year period. The year 2007 has so far remained as the year with the best figures in the TEUs transported. More than 2,100,000 TEUs passed through the Port of Virginia. At the Port of Virginia, transport of freight is by barge inland, road or rail through their port with VIP as the sole inland point of destination. VIP has encouraged attraction of 24 distribution and warehousing centers. This in financial terms has provided a total of US\$599m in income together with space of 56 hectares approximately and 7,000 firms as employers (Edward, 2007). The Port of Virginia has been able to cut pollution levels by 38 per cent through modal shifting to rail from road after the 1999 year period (The Port of Virginia, 2007 cited by Henttu et al., 2010, p. 21).

Another inland container port terminal is the Dry Port of Isaka, which also serves Rwanda, Burundi and Democratic Republic of Congo. It obtained dry port grade in the year 1999. Conversion of Isaka to dry port implies all customs official documentation could be processed at Isaka instead of the Port of Dar es Salaam. As a station for railway transport till the latter 1980s, Isaka began to progress to the level of a central commercial activity place stemming from the steady rising traffic on the highway toward Rwanda. Isaka has currently been handling both export and import traffic directly after the year 1999. The main components of Isaka include Isaka Railway Station with goods as well as passenger terminals and Inland dry port facility.

The Isaka dry port offers a suitable link for traffic into north-east Democratic Republic of Congo as well as Rwanda. Isaka serves an important transport connection from and to Rwanda found on the Tanzania Railways Corporation (TRC) line amid Tabora and Mwanza. The Isaka terminal for containers is under the operations and management of the TRC. With the TRC's infrastructure, it is able to handle cargo worth 1.8 million metric tons each year. Isaka dry port is situated in the region of Shinyanga handling goods with Democratic Republic of Congo, Rwanda or Burundi as final destination. Isaka Dry Port provides convenient, safe and secure, as well as fast custom clearance of cargo with reduced demurrage charges, faster transit time, cost effective, preferential wagon allocation, low transport cost and overall efficiency services. The port also deals with general dry cargo as well as containerized ones. With two transit sheds of 7,000 metric tons storage capacities each, the port facility is able to handle 42,583 metric tons of loose cargo every year. There are two sidings of railway with a 22-wagon capacity at a go serving the yards (FDT, 2007).

\section{Data and methodology}

The gravitational method was used to research how the location of Boankra Inland Port will minimize cost of transportation compared to the two main seaports in Tema and Takoradi. Data for the gravitational model are distances from the main seaports in Ghana and Boankra Inland Port to major hinterland destinations and population of the destinations. The distance between the ports and the hinterland destinations was multiplied with the population of the destinations. Thus:

$$
\mathrm{Tc}=\sum \mathrm{DnP}
$$

where

$\mathrm{Tc}=$ Total transportation cost;

$\mathrm{Dn}=$ Distance from distribution center to destination; and

$\mathrm{P}=$ Population of destination. 
Afterwards, all the values for each destination were added to get the total value. The port with the minimum total value was chosen as the most cost-efficient to be used as a distribution center. Again, the view of experts in the transport industry, the academia and employees from the logistics sector with relevant technical, operational and functional backgrounds was used in the study. The respondents were selected from Ghana Shippers' Authority, GPHA, Ghana Railway Corporation and major shipping lines such as Maersk Line and other third-party logistics companies. A total of 210 respondents were asked to examine the advantages of the dry port implementation in Ghana. Secondary data for the study were obtained from Google Maps and Ghana Shippers Council Reports.

\section{Results and discussion}

\section{Results of gravitational model}

The gravitational model was used to compare selected distribution centers and their costs of transportation. Of all, 21 cities and towns which serve as origin and destination of cargo were selected. Tema, Takoradi and Boankra were also selected as the distribution centers. Tema and Takoradi were selected because they are the main seaports in Ghana. Boankra was also selected as a distribution center because it is the location for the proposed inland port. All the 21 cities and towns selected have road networks that link them to the three locations selected as distribution centers. The distances between the 21 cities and towns and the distribution centers was gathered through an internet source (Google Maps, 2016). The road distances are shown in Table II. The population of the 21 cities and towns was also researched. The list of cities and their population can be seen in Table II.

The data required for this model were the distances from the distribution centers to the 21 cities and towns and their population. The distances between the distribution centers and the cities and towns were multiplied by their population to determine transportation costs.

\begin{tabular}{|c|c|c|c|c|c|}
\hline \multirow[b]{2}{*}{ City } & \multirow[b]{2}{*}{ Population } & \multicolumn{3}{|c|}{ Distance between seaports and destinations } & \\
\hline & & Tema $(\mathrm{km})$ & Takoradi (km) & Boankra (km) & \\
\hline Wa & 102,446 & 712 & 700 & 456 & \\
\hline Bolgatanga & 66,685 & 757 & 798 & 554 & \\
\hline Yendi & 52,008 & 492 & 729 & 489 & \\
\hline Bawku & 69,527 & 707 & 867 & 623 & \\
\hline Navrongo & 27,306 & 787 & 829 & 585 & \\
\hline Tamale & 537,986 & 593 & 634 & 390 & \\
\hline Sunyani & 87,642 & 394 & 376 & 137 & \\
\hline Berekum & 60,473 & 426 & 409 & 170 & \\
\hline Kintampo & 27,369 & 450 & 437 & 193 & \\
\hline Techiman & 99,721 & 388 & 376 & 132 & \\
\hline Kumasi & $1,989,062$ & 270 & 259 & 24 & \\
\hline Ejura & 70,807 & 342 & 350 & 95 & \\
\hline Konongo & 41,238 & 221 & 308 & 37 & \\
\hline Obuasi & 175,043 & 276 & 202 & 79 & Table II. \\
\hline Takoradi & 445,205 & 209 & 0 & 272 & Road network \\
\hline Nkawkaw & 60,427 & 165 & 318 & 92 & Road network \\
\hline Koforidua & 127,334 & 86 & 290 & 181 & distances between \\
\hline Accra & $2,291,352$ & 23 & 223 & 238 & distribution centers \\
\hline Tema & 160,939 & 0 & 245 & 256 & and -21 cities/towns \\
\hline Ho & 96,213 & 137 & 371 & 302 & (DFS) and their \\
\hline Cape Coast & 217,032 & 169 & 79 & 245 & population (PD) \\
\hline
\end{tabular}


MABR

2,3

\section{4}

The distribution center with the least total transportation cost is considered to be the most cost-efficient choice. The Table III shows the transportation costs of inland road transportation in Ghana.

The table shows that the total transportation cost is lowest when Boankra is chosen as a distribution center. Tema's total transporation cost is 14 per cent higher than Boankra. Takoradi's total transportation cost is 48 per cent more expensive than Boankra. With regard to this analysis, Boankra as a location for a distribution center is better than Tema and Takoradi. A further comparison between Tema and Takoradi shows that Tema has a better location as a distribution center than Takoradi. The results of the gravitational model therefore support the choice of Boankra as the location for an inland port. Although Tema and Takoradi are the main seaports in Ghana, the implementation of the Boankra inland port will reduce the transportation cost for cargo with hinterland destinations, therefore making it a rational and cost-efficient location for transit transportation.

\section{Warehousing capacity}

It is imperative to assess the warehousing capacity of the Boankra Inland Port because of the fact that adequate space is required to store and load containers and also to cater for future expansion in case of increase in container traffic. Boankra is located $24 \mathrm{~km}$ east of Kumasi and in the Ejisu-Juaben district. The northern end of the site is located $100 \mathrm{~m}$ from the Kumasi - Accra highway. The size of the site is about 400 acres (160 hectares) of which approximately 60 per cent was estimated suitable for development of the inland port with extensive ground works. This gives Boankra a high potential of warehousing capacity and also space for future expansion.

Large hectares of land have been reserved for empty container storage and also for construction of container terminals. The Ghana Shippers Authority has put in place the

\begin{tabular}{lrrr}
\hline City & \multicolumn{1}{c}{ Tema } & \multicolumn{1}{c}{ Takoradi } & \multicolumn{1}{c}{ Boankra } \\
\hline Wa & $72,941,552$ & $71,712,200$ & $46,715,376$ \\
Bolgatanga & $50,480,545$ & $53,214,630$ & $36,943,490$ \\
Yendi & $25,587,936$ & $37,913,832$ & $25,431,912$ \\
Bawku & $49,155,589$ & $60,279,909$ & $43,315,321$ \\
Navrongo & $21,489,822$ & $22,636,674$ & $15,974,010$ \\
Tamale & $319,025,698$ & $341,083,124$ & $209,814,540$ \\
Sunyani & $34,530,948$ & $32,953,392$ & $12,006,954$ \\
Berekum & $25,761,498$ & $24,733,457$ & $10,280,410$ \\
Kintampo & $12,316,050$ & $11,960,253$ & $5,282,217$ \\
Techiman & $38,691,748$ & $37,495,096$ & $13,163,172$ \\
Kumasi & $537,046,740$ & $515,167,058$ & $47,737,488$ \\
Ejura & $24,215,994$ & $24,782,450$ & $6,726,665$ \\
Konongo & $9,113,598$ & $12,701,304$ & $1,525,806$ \\
Obuasi & $48,311,868$ & $35,358,686$ & $13,828,397$ \\
Takoradi & $93,047,845$ & 0 & $121,095,760$ \\
Nkawkaw & $9,970,455$ & $19,215,786$ & $5,559,284$ \\
Koforidua & $10,950,724$ & $36,926,860$ & $23,047,454$ \\
Accra & $52,701,096$ & $510,971,496$ & $545,341,776$ \\
Tema & 0 & $39,430,055$ & $41,200,384$ \\
Ho & $13,181,181$ & $35,695,023$ & $29,056,326$ \\
Cape Coast & $36,678,408$ & $17,145,528$ & $53,172,840$ \\
& $1,485,199,295$ & $1,941,376,813$ & $1,307,219,582$ \\
\hline
\end{tabular}

Table III.

Distribution costs of inland road transportation in Ghana
$36,678,408$
$1,485,199,295$
$1,941,376,813$

$71,712,200$

$60,279,909$

$22,636,674$

24,733,457

$515,167,058$

$12,701,304$

0

$36,926,860$

$510,971,496$

$39,430,055$

$35,695,023$

1,941,376,813
46,715,376

25,431,912

43,315,321

209,814,540

$12,006,954$

$10,280,410$

$13,163,172$

$47,737,488$

$6,726,665$

$1,525,806$

$121,095,760$

$5,559,284$

23,047,454

$545,341,776$

$29,056,326$

$1,307,219,582$ 
necessary measures to cater for any future increase in container traffic. It is also expected that private warehouses will be constructed for container storage. Also, the inland port is well connected to both the national rail and road networks of Ghana. The western railway line connects Takoradi to Kumasi which is also connected to Boankra. The eastern railway line which connects Kumasi to Accra passes through the northern end of the Boankra inland port site. Boankra has a strategic location which is at the top of a triangular road network of Kumasi, Takoradi and Tema. Most containers from Tema and Takoradi (which are the main seaports) that are transported to the hinterland and the landlocked Sahelian countries such as Mali, Burkina Faso and Niger pass through Kumasi. For future road expansion, a zone of about $100 \mathrm{~m}$ on both sides of the Accra-Kumasi highway has been earmarked (Royal Haskoning, 2002).

A crucial factor that is considered in the implementation of dry ports is the availability of space for container storage and future expansion. Information gathered so far indicates availability of space for the implementation of Boankra inland port, but the acquisition of more land for future expansion will be difficult and expensive. This will therefore limit the benefits of the inland port.

\section{Questionnaire analysis}

Respondents of the questionnaires and interviews were from the academia and logistics sector mainly shipping lines and third-party logistics companies. A total of 132 respondents answered the questionnaires. Of all, 77 per cent of them were male and 23 per cent were female; 32 per cent of the respondents were aged between 20 and 30, 51 per cent aged between 31 and 40, 14 per cent aged between 41 and 50 and a relatively small percentage of four per cent were aged above 50; 9 per cent of the respondents were educated up to the diploma level which is relatively lower than those educated to degree level which was 73 per cent; and 18 per cent were holders of master's degree.

\section{Advantages and disadvantages of the dry port implementation in Ghana}

A majority of the respondents believe that the key benefit of the implementation of the dry port is the better efficiencies at the main seaports because of the reduction of congestion as volumes of containers will be reduced. According to the respondents, there will be other benefits such as reduction of road traffic, as there is going to be a reduction in the number of trucks that move to the seaport cities to transport containers to the hinterlands and other countries. Also they believe, it will make the movement or transportation of cargo faster. There will be a reduction in the cost of road repairs because rail network will be operational, consequently reducing strain on roads, especially in the seaport cities. This is because of the fact that a single train can transport a considerable number of containers. Some respondents, on the one hand, also believe an implementation of a dry port will facilitate international trade between Ghana and the landlocked countries and improve the economic growth of Boankra and the surrounding towns. On the other hand, the respondents believe that the usual delay in clearing of cargo at the main seaports coupled with inefficient rail network may cause delays in clearing cargo at the inland port, therefore increasing lead times. Also, they assumed that the dry port implementation will decrease economic activities at the seaport cities, and small and medium trucking companies may also fold up as cargo to hinterland destinations will be transported by rail.

The economic development of Ghana hinges very much on the annual revenue and employment from the ports. Tema Port has a significant impact locally, regionally and nationally (Olukoju, 1996). Olukoju (1996) further argues that in some countries, such as 
MABR

2,3

\section{6}

Singapore, seaport is the leading sector supporting the GDP. Tema Port plays a major role in the development of industries in Ghana. Industries such as steel plants, refinery and power plants which are mainly export and import based depend a lot on the port. The deep draft mechanized feature of the Tema Port supports all the importation needs of these companies. Development of industries around Tema and its environments is highly influenced by the presence of Tema Port. Tema is usually described as the industrial city of Ghana. Sea port operations generate a lot of revenue for governments around the world (Zhu and Kotz, 2010). The Government of Ghana also depends heavily on import duties/ revenue (Asuliwonno, 2011; Acquah-Bentil, 2015). Acquah-Bentil (2015) argue that revenue generation at the port has seen steady growth between 1999 and 2013. To enhance revenue mobilization at the port, Government of Ghana introduced Ghana Community Network Services Limited (GCNET) revenue mobilization system in 2000. This has improved import revenue mobilization at the port (Asuliwonno, 2011). For instance, a recent report by GPHA (2016) indicates an increase in their profit from US $\$ 28 \mathrm{~m}$ (GHC 53.69m) in 2012 to about US\$88.6m (GHC 335.79m). Takoradi and Tema ports have experienced about 40 per cent throughput since 2009. The ports handle more than 17 million tons of containers a year (GHPA, 2016).

\section{Conclusion}

The main purpose of this research was to assess the potentials of integrating Boankra Inland Port into the supply chain in Ghana. The findings suggest that Boankra inland port will serve as a more efficient solution to the congestion at the ports than building container terminals at the seaports. The economic effects of the implementation of the inland port are reduction in the total transportation expenses and the external costs, strengthening of the role of the main seaports in transport chains, as well as multimodal solutions. It will also facilitate a greater level of international trade with landlocked countries, industrial growth in the hinterland and economic boom in Boankra and the surrounding towns. Again, environmental problems and traffic bottlenecks at the seaport cities will be reduced, as volumes of containers will be moved to the inland port for clearance. The study also revealed that Boankra has a good location to serve as a transit point for hinterland bound cargo. Based on the gravitational model, Boankra's position as a distribution center is a critical competitive tool for the seaport (Roso, 2009b). Also, the assessment of the warehousing capacity of Boankra shows that there is adequate space available to handle containers. There is also enough land available at the inland port area to cater for an increase in container traffic and future expansion.

In the opinion of respondents, challenges which may affect the implementation of the inland port are inadequate source of funding, lack of government commitment, inadequacy of expertise, lack of rail infrastructure and land ownership/tenure system. Again, they envisage that reduction in the economic activities around seaports, potential delay in clearing cargo because of poor rail network; huge capital outlay and the collapsing of small and medium trucking companies are some of the consequences of the inland port implementation. In future, a cost model may be applied to compare rail and road transport to provide more accurate comparison of conventional road transport and intermodal transport. Forecast of future increase in container traffic of hinterland destinations should be carried out to plan for future expansion of the inland port. The potential of the implementation of the inland port should be stressed to allow the public and policy makers to have more knowledge about it, and therefore its adoption. 


\section{References}

Acquah-Bentil, E. (2015), "Statistical analysis of the impact of the Gcnet on Revenue performance in Ghana: a case study of Tema Port”, Master of Philosophy Theses, University of Ghana, Ghana.

Asuliwonno, C. (2011), "Improving port efficiency and customs operation in Ghana: a case study of Ghana community network service limited”, Master of Science Dissertation, Kwame Nkrumah University of Science and Technology, Kumasi, Ghana.

Bergqvist, R. and Woxenius, J. (2011), "Hinterland transport by rail - the story of Scandinavia and Port of Goteburg", Journal of Interdisciplinary Economics, Vol. 23 No. 2, pp. 161-175.

Chopra, S. and Meindl, P. (2007), Supply Chain Management: Strategy, Planning, and Operation, 3rd ed., Prentice Hall, Upper Saddle River, NJ.

Ghana National Development Planning Commission (2013), Medium-Term National Development Policy Framework, National Development Commission, Accra.

Global Intellectual Property Center (2015), Unlimited Potential, US Chamber of Commerce, GIPC International IP Index.

Henttu, V., Lättilä, L. and Hilmola, O.P. (2010), "Financial and environmental impacts of a dry port to support two major Finnish seaports", Lappeenranta University of Technology, Department of Industrial Management, Research Report 224.

Notteboom, T. and Rodrigue, J.P. (2005), "Port regionalization: towards a new phase in port development", Maritime Policy and Management, Vol. 32 No. 3.

Olukoju, A. (1996), Maritime Trade, Port Development and Administration: The Japanese Experience and Lessons for Nigeria, IDE, Tokyo.

Port of Göteborg AB (2008), Rail, Road \& Logistics, Port of Göteborg AB, Göteborg.

Roso, V. (2006), Emergence and Significance of Dry Ports, Chalmers University of Technology, Sweden Division of Logistics and Transportation, Goteburg.

Roso, V. (2009), "The dry port concept", doctoral thesis, Department of Logistics and Transportation, Chalmers University of Technology, Goteborg.

Roso, V., Woxenius, J. and Lumsden, K. (2008), “The dry port concept: connecting container seaports with the Hinter land", Journal of Transport Geograph.

Roso, V., Woxenius, J. and Olandersson, G. (2006), Organization of Swedish Dry Port Terminals, Division of Logistics and Transportation, Chalmers University of Technology, Goteburg.

Woxenius, J., Roso, V. and Lumsden, K. (2004), "The dry port concept - connecting seaports with their Hinterland by rail", ICLSP, Dalian, 22-26 September.

Zhu, A. and Kotz, D.M. (2010), “The dependence of China's economic growth on exports and investment", pp. 4-37.

\section{Further reading}

Ghana Ports and Harbours Authority (2013), Port Tarriffs, GPHA Press, Tema.

Ghana Shippers Authority (2013), "Projects”, available at: http://shippers.org.gh/?page_id=225

Rodrigue, J.P. and Notteboom, T. (2012), "Dry ports in European and North American intermodal rail systems: two of a kind?", Research in Transportation Business \& Management, Vol. 5, pp. 4-15.

Rodrigue, J.P. and Notteboom, T. (2013), "The containerization of commodities", in Rodrigue, J.P., Comtois, C. and Slack, B. (Eds), The Geography of Transport System, 3rd ed., Routledge, New York, NY.

Roso, V. (2008), "Factors influencing implementation of a dry port", International Journal of Physical Distribution and Logistics Management, Vol. 38 No. 10, pp. 782-798. 
MABR

2,3

\begin{tabular}{|c|c|c|c|c|c|}
\hline \multirow{4}{*}{278} & City & Population & Tema $(\mathrm{km})$ & Takoradi (km) & Boankra (km) \\
\hline & Wa & 102,446 & 712 & 700 & 456 \\
\hline & Bolgatanga & 66,685 & 757 & 798 & 554 \\
\hline & Yendi & 52,008 & 492 & 729 & 489 \\
\hline \multirow{18}{*}{$\begin{array}{l}\text { Table AI. } \\
\text { Road network } \\
\text { distances between } \\
\text { distribution centers } \\
\text { and } 21 \text { cities and } \\
\text { towns and their } \\
\text { population }\end{array}$} & Bawku & 69,527 & 707 & 867 & 623 \\
\hline & Navrongo & 27,306 & 787 & 829 & 585 \\
\hline & Tamale & 537,986 & 593 & 634 & 390 \\
\hline & Sunyani & 87,642 & 394 & 376 & 137 \\
\hline & Berekum & 60,473 & 426 & 409 & 170 \\
\hline & Kintampo & 27,369 & 450 & 437 & 193 \\
\hline & Techiman & 99,721 & 388 & 376 & 132 \\
\hline & Kumasi & $1,989,062$ & 270 & 259 & 24 \\
\hline & Ejura & 70,807 & 342 & 350 & 95 \\
\hline & Konongo & 41,238 & 221 & 308 & 37 \\
\hline & Obuasi & 175,043 & 276 & 202 & 79 \\
\hline & Takoradi & 445,205 & 209 & 0 & 272 \\
\hline & Nkawkaw & 60,427 & 165 & 318 & 92 \\
\hline & Koforidua & 127,334 & 86 & 290 & 181 \\
\hline & Accra & $2,291,352$ & 23 & 223 & 238 \\
\hline & Tema & 160,939 & 0 & 245 & 256 \\
\hline & Ho & 96,213 & 137 & 371 & 302 \\
\hline & Cape Coast & 217,032 & 169 & 79 & 245 \\
\hline
\end{tabular}

Corresponding author

Kwame Owusu Kwateng can be contacted at: kowusukwateng@yahoo.com

For instructions on how to order reprints of this article, please visit our website: www.emeraldgrouppublishing.com/licensing/reprints.htm

Or contact us for further details: permissions@emeraldinsight.com 